\title{
Head and Neck Lymph Node
}

National Cancer Institute

\section{Source}

National Cancer Institute. Head and Neck Lymph Node. NCI Thesaurus. Code C12358.

Lymph nodes found within the head and neck region of the body, which drain into the deep cervical nodes, either directly or indirectly. These include the occipital, mastoid, parotid, facial, retropharyngeal, submandibular, submental, lingual and cervical lymph nodes. Any lymph node located in the head or neck. 